University of Wollongong

Research Online

Faculty of Social Sciences - Papers (Archive) Faculty of Arts, Social Sciences \& Humanities

2015

Conceptualizing metalinguistic understanding in writing I

Conceptualización de la competencia metalingüística en la escritura

Debra Myhill

University of Wollongong, d.a.myhill@ex.ac.uk

Susan M. Jones

University of Exeter

Follow this and additional works at: https://ro.uow.edu.au/sspapers

Part of the Education Commons, and the Social and Behavioral Sciences Commons

Research Online is the open access institutional repository for the University of Wollongong. For further information contact the UOW Library: research-pubs@uow.edu.au 


\title{
Conceptualizing metalinguistic understanding in writing | Conceptualización de la competencia metalingüística en la escritura
}

\author{
Abstract \\ This paper will present a theoretical analysis of research on metalinguistic understanding, illustrating how \\ current research does not yet adequately address metalinguistic development in writing. Existing \\ research on metalinguistic understanding has focused more on language acquisition, oral development \\ and bilingual learners. Research on metalinguistic understanding in writing has tended to look more \\ closely at young learners developing writing skills in spelling, transcription and orthography. Thus, \\ theoretical accounts of metalinguistic understanding are currently insufficient to explain developing \\ metalinguistic mastery of composing text and the relationships between declarative and procedural \\ metalinguistic knowledge in writing. If we are to understand better the nature of metalinguistic \\ understanding in relation to writing in learners in the later phases of compulsory education, it is important \\ to develop theoretical clarity about the key concepts involved in order to frame empirical studies which \\ are both conceptually and methodologically rigorous and educationally relevant.
}

\section{Keywords}

conceptualizaci, n, de, la, competencia, metaling, stica, en, escritura, conceptualizing, metalinguistic, understanding, writing

\section{Disciplines \\ Education | Social and Behavioral Sciences}

\section{Publication Details}

Myhill, D. \& Jones, S. (2015). Conceptualizing metalinguistic understanding in writing | Conceptualización de la competencia metalingüística en la escritura. Culture and Education, 27 (4), 839-867. 


\section{CONCEPTUALISING METALINGUISTIC UNDERSTANDING IN WRITING}

Debra Myhill - University of Exeter, UK University of Wollongong, Australia

Susan Jones - University of Exeter, UK

\section{Abstract}

This paper will present a theoretical analysis of research on metalinguistic understanding, illustrating how current research does not yet adequately address metalinguistic development in writing. Existing research on metalinguistic understanding has focused more on language acquisition, oral development, and bilingual learners. Research on metalinguistic understanding in writing has tended to look more closely at young learners developing writing skills in spelling, transcription and orthography. Thus theoretical accounts of metalinguistic understanding are currently insufficient to explain developing metalinguistic mastery of composing text and the relationships between declarative and procedural metalinguistic knowledge in writing. If we are to understand better the nature of metalinguistic understanding in relation to writing in learners in the later phases of compulsory education, it is important to develop theoretical clarity about the key concepts involved in order to frame empirical studies which are both conceptually and methodologically rigorous and educationally relevant. 


\section{Introduction}

Historically, theoretical understanding of metalinguistic understanding has scarcely addressed the issue in the context of writing, other than in relation to early years writing development where there is a substantial body of work. Consequently, there is very limited understanding of how older writers in the secondary or high-school phase of schooling develop metalinguistic understanding about writing. Yet writing, by its very nature, is always an act of decision-making (Kellogg, 1994): decisions about the communicative content, about the medium, about the audience, about text structure, about word choice and so on. Arguably, writing is always an act of selecting, shaping, reflecting and revising (Myhill, 2011) and thus draws on metalinguistic activity. Indeed, researchers such as Tolchinsky (2000) and Fortune (2005) have argued that metalinguistic activity is an inevitable element of text production - in other words, it is impossible to write without engaging in metalinguistic activity at some level.

However, it also needs to be recognised that to an extent, 'metalinguistic' is a problem word, largely because of its grammatical role as an adjective. This stands in contrast to the abstract noun designation of its sister word, 'metacognition'. It is an irony that a word which is used to describe grammatical knowledge should itself be ambiguous as a consequence of its grammatical designation. Its adjectival function means it must always premodify another noun, leading to less conceptual clarity around metalinguistic ideas than is the case with the concept of metacognition (Camps \& Milian, 1999:4; Myhill, 2011:249; Fontich \& Camps 2014)). So the research literature variously refers to metalinguistic awareness; metalinguistic knowledge; metalinguistic understanding; metalinguistic activity; metalinguistic behaviour and so on. Each noun subtly alters what the conceptual focus might be and raises fundamental theoretical questions about what the distinction might be between, for example, metalinguistic awareness and metalinguistic understanding. As a consequence, researchers frequently use the various nouns which can follow 'metalinguistic' as synonyms of each other, or imply conceptual differences between them which are unexplained.

At the same time, the concept is considered rather differently through different disciplinary lenses. Psychology focuses on the cognitive processes that metalinguistic understanding fosters, the monitoring, regulatory function of selecting and shaping language. It is the individual's thinking processes which are important rather than the spoken or written output. Conversely, in linguistics, it is the text or utterance which has primacy, the language or text is an artifact. The focus is on the metalanguage of linguistic description, the terminology used to describe language. Drawing particularly on Hallidayian notions of language and grammar as 'abstract semiosis' (Halliday \& Mathiessen, 2004:15), a socio-cultural lens offers a focus on how human interaction shapes metalinguistic understanding, learning how to mean. This stance builds on Vygotsky's view of writing as social and cultural interaction which requires 'deliberate semantics deliberate structuring of the web of meaning' (1986:182). (For a further discussion of this, see Camps \& Milian 1999:5 and Fontich \& Camps 2014)

This grammatical and disciplinary ambiguity has led to some conceptual fuzziness in the research, with different researchers using the word 'metalinguistic' to mean different things, and with surprisingly few offering clear definitions even when metalinguistic concepts are at the heart of the research. Amongst those who do, the various definitions are not wholly consensual. For example, Roth, Spence, Cooper, and la Paz's definition that metalinguistic skill represents 'the ability to objectify language and dissect it as an arbitrary linguistic code independent of meaning' (1996:258) would be at odds with Halliday's conceptualisation of an integrated relationship between language and meaning. Jakobson (1963) argued that the metalinguistic function was the use of language to comment on and reflect upon itself, on language as an object. This has affinity with Camps and Milian's definition, 'the ability to take language as the object of observation and the referent of discourse' (1999:6). Cazden (1976) conceptualises metalinguistic understanding in terms of a switch from using language to communicate to a focus on the language itself: those moments when users 
'shift their attention from the transmitted contents to the properties of language used to transmit them' (1976:3). Our own definition, drawing both on theoretical perspectives in the literature and on data analysis from our own projects attempts to adopt an interdisciplinary theoretical frame by considering metalinguistic understanding as 'the explicit bringing into consciousness of an attention to language as an artifact, and the conscious monitoring and manipulation of language to create desired meanings grounded in socially shared understandings' (Myhill, 2012:250).

\section{Metalinguistic Development}

Gombert's (1992) analysis of metalinguistic development remains seminal within the field, although it focuses principally on oral development in the early years. He conceptualised metalinguistic development as having five subdomains:

- Metaphonological: developing understanding of the sounds that build words

- Metalexical/metasemantic: developing understanding of word structures and word meanings;

- Metasyntactic: developing the ability to reason consciously about syntax and intentionally control it;

- Metapragmatic: developing understanding of how to use language appropriately in social contexts;

- Metatextual: developing understanding of text structure including cohesion and coherence.

Gombert argued that metaphonological, metalexical/semantic and metasyntactic understanding developed before metapragmatic and metatextual understanding. He also distinguished between two levels of cognitive control over language use, the epilinguistic and the metalinguistic (Gombert, 1992; 2003) and provided very clear definitions of each:

Metalinguistic: 'subfield of metacognition concerned with language and its use - in other words comprising : 1) activities of reflection on language and its use; 2) subjects' ability intentionally to monitor and plan their own methods of linguistic processing (in both comprehension and production)'

Epilinguistic: 'behaviour manifested from an early age which is related to metalinguistic behaviour but is not...consciously monitored by the subject. Such activities in the subjects behaviour are, in fact, explicit manifestations of a functional awareness of the rules of the organization or use of language'. (Gombert, 1992:13)

The epilinguistic level describes those automatic linguistic processes which occur without conscious control; whereas the metalinguistic level refers to 'the control consciously chosen, decided on and applied by the individual' (Gombert, 2003: 3). In essence, Gombert is suggesting that linguistic competence precedes conscious linguistic control (ie metalinguistic understanding). This notion of unconscious or automatic processing contrasted with conscious knowledge figures also in the work of Culioli (1990) who proposed three stages of awareness, and Karmiloff-Smith, Grant, Sims, and Cuckle (1996) who propose four phases. The use of the term 'phases' rather than 'stages' is important here: these are not developmental stages but phases that anyone, of any age, may undergo when confronted with a new problem in any knowledge domain. In the context of language acquisition, these conceptualisations seem plausible as we know that children learn to speak and communicate effectively before they can consciously understand and manipulate their spoken language. But it is less apparent how well this transfers to the development of metalinguistic understanding in writing. For example, very young children learning to read are usually consciously aware of words, of spelling, and of sentence punctuation because teaching draws attention to these aspects.

As noted earlier, existing research into metalinguistic development or understanding has tended to investigate within the context of younger learners, second language learners, or oral development. There 
are few studies that have examined metalinguistic understanding in relation to writing. Where these exist, studies in this area have been limited to the role of metalinguistic understanding in developing spelling competence, particularly in terms of metaphonological and metaorthographic knowledge. These studies, however, focus upon early writing development, or dyslexic writers. Table 1 below offers a snapshot overview of the research into metalinguistic understanding, and reveals clearly the paucity of research into writing beyond transcriptional and orthographic aspects.

\begin{tabular}{|l|l|}
\hline Research focus & Authors \\
\hline Oral development & Downing \& Oliver, 1974; Gombert, 1992; \\
\hline Reading comprehension & $\begin{array}{l}\text { Hiebert, Cioffi \& Antonak, 1984; MacGillivray, 1994; } \\
\text { D'warte, 2012 }\end{array}$ \\
\hline Second Language Learning & $\begin{array}{l}\text { Cisero \& Royer, 1995; Norbert, 1999; Bialystok, 2007; Hu, } \\
\text { 2010; Bialystok \& Barac, 2012 ; Ellis, 2009 }\end{array}$ \\
\hline Early Years' Learning & Karmiloff-Smith et al., 1996; Martello, 2001; Lin et al. 2011 \\
\hline Spelling Development & $\begin{array}{l}\text { Nunes, Bryant \& Bindman, 2006; Bourassa, Treiman \& } \\
\text { Kessler, 2006 }\end{array}$ \\
\hline Handwriting Development & Caravolas, Kessler, Hume \& Snowling, 2005 \\
\hline
\end{tabular}

Table 1: overview of research into metalinguistic understanding

\section{Metalinguistic Understanding in Writing}

Nonetheless, Gombert (1992) did recognise some of the specific demands of writing and that metalinguistic understanding in writing may be different from that related to talk. He notes that the absence of an immediate reader and immediate feedback makes writing more challenging, 'the cognitive consequence of [this...] is the higher level of abstraction and elaboration required in the processing of written language' (1992:151) and suggests that, as a consequence, 'metalinguistic development thus appears to be of primary importance in the acquisition of writing'. He also argues that metalinguistic activity is, to an extent, an inevitable consequence of the demands of writing because 'most of the components of the activity of writing are consciously monitored by the subject at some stage during the learning process, from first acquaintance with activity of writing to expertise in the production of written text' (1992:17).

Our own research addressing metalinguistic understanding in secondary writers (Myhill, 2011) considered the verbalizable metalinguistic understanding articulated by writers about decision-making in their own texts. The data was drawn from a larger study (Myhill et al., 2012), involving a randomised controlled trial investigating the impact on written outcomes of explicit teaching of functionally-oriented grammar. A sample of focus children in each class engaged in 'writing conversations' with researchers, focused on a piece of their own writing and a piece by another student, outlining their writing intentions, decisions and evaluations. Using Gombert's taxonomy as a starting-point, the study found some commonality with Gombert in that these writers demonstrated greater levels of confidence and competence discussing metalexical/metasemantic decisions than metatextual decisions. However, they were considerably less assured in discussing metasyntactic choices, largely because their declarative syntactical knowledge was limited. Gombert's category of metapragmatic understanding - understanding of language in a social context - proved less useful as for these older writers almost all of the comments deemed to be metalinguistic related to the socially-determined audience and purpose of the writing. It may be that Gombert's taxonomy has less validity in the context of writing by older children.

One key difference between writing and oral development is that writing is almost exclusively learned through direct instruction - whilst we learn to talk through meaningful social interactions with those around 
us, in general we learn to write in formal school contexts with explicit teaching input. Growing understanding of the metaphonological and metalexical/metasemantic aspects of words, and the metatextual and metapragmatic aspects of language can emerge through language experience, though, of course, explicit teaching is likely to enhance this. But Gombert singles out metasyntactical understanding as one aspect of metalinguistic development which does not occur naturally, and he argues that 'it is through school work on the formal aspects of language, in particular the explicit learning of grammatical rules and in the corresponding practical exercises...that the necessity for metasyntactic behaviour...might be seen to emerge' (1992:62). Whilst we would disagree on the need for learning rules or for undertaking exercises, it is nonetheless true that it is harder to develop metasyntactical knowledge without teacher input, and it is harder to discuss syntactical features without grammatical metalanguage. The lack of confidence discussing syntactical choices in the students in our study is testimony to this. More generally, teaching input on writing can support children in understanding metapragmatic issues about how texts are influenced by social and cultural contexts, and metatextual issues considering, for example, text genres and the typical linguistic structures which underpin different genres. Thus the teacher's role in developing metalinguistic understanding in writing is critical and there is a strong relationship between what is taught and what is learned. In our study, one strong finding was that students in their writing conversations with us frequently echoed directly the teaching input, using metalanguage, but without any evident depth of understanding. For example, one student explained that his writing would be improved by the use of 'short connectives ... you can emphasise them a lot and you can put a lot more expression in', whilst another explained that 'you don't really worry about the amount of nouns because there might be a lot of people in it and you're not really sort of thinking about the nouns, but the describing words and the adjectives, well the adjectives and verbs and stuff'. Here the metalanguage has been learned but without the accompanying metalinguistic understanding that might support these writers in a more critical understanding of their own and others' writing. It does seem, therefore, that one significant aspect of metalinguistic development in writing which merits more serious attention is the inter-relationship between teaching and learning.

\section{Metalanguage and Writing}

One way in which teaching is instrumental in developing metalinguistic understanding is in introducing students to the metalanguage which is useful to discuss writing. Here the research tends to conflate metalanguage and grammatical metalanguage as one and the same thing, without acknowledging that there is a broader set of metalinguistic categories for writing. In addition to grammatical metalanguage, older writers in the secondary or high school are highly likely to be introduced to at least three other categories of metalanguage for writing: literary, genre-specific, and process. Literary metalanguage, such as metaphor, imagery, or allusion is frequently learned through the teaching of literature, and subsequently used in the discussion of writing, perhaps especially creative writing. Wilson and Myhill (2012) found that in England, where there is no history of teaching grammar and where the dominant route into English teaching is via an English Literature degree, teachers hold ambivalent and, at times, contradictory personal epistemologies towards literary and linguistic metalanguage in the context of teaching writing. On the one hand, they value the role of literary metalanguage as essential to the teaching of a creative, expressive subject but construct linguistic, grammatical metalanguage as restrictive and bound by rules and constraints. This links to their substantially greater confidence with literary analysis and literary metalanguage, compared with their grammatical knowledge. Genre-specific metalanguage is strongly linked to curriculum models for the teaching of writing which place a heavy emphasis on the explicit teaching of genre, notably Australia, New Zealand and England. This approach draws heavily on the work of the Sydney School of genre theorists (Martin, 1985; Rose, 2009) and whilst some of the metalanguage (eg field; tenor; mode) is directly related to Systemic Functional Linguistics, there is also metalanguage specifically linked to particular genres. So, for example, the teaching of how to write a newspaper article might well include references to straplines, headlines, columns or captions, whilst the teaching of narrative might include narrative hooks, setting, climax 
or resolution. Finally, classrooms which subscribe to process approaches to the teaching of writing as advocated by Graves (1983), Murray (1982) and Calkins (1983) are likely to be taught metalanguage linked to the process of writing, such as drafting, proof-reading, editing, outlining and so on. It is important, therefore, to remember that metalinguistic development in writing is more comprehensive than simply grammatical knowledge and reflects socio-cultural understanding (genre theory) and cognitive understanding (the writing process) as well as linguistic understanding. It also re-emphasises the point made earlier that there is a close relationship between what metalinguistic learning writers develop and what they are taught (and, by implication, what curriculum model governs the teaching of writing).

Nonetheless, grammatical metalanguage does have a particular role to play in developing metalinguistic understanding of writing, yet in common with the general trend to focus on metalinguistic issues in other areas of language learning, there is very little research focused on first language speakers and writing in the older years. There is considerable attention to the role of metalinguistic awareness, what Gombert (1992) would have deemed epilinguistic, in initial language acquisition (Bereiter \& Scardamalia, 1987; Cioffi, 1984; Dahl \& Freppon, 1995; Graves, 1983; MacGillivray, 1994). There is also a substantial focus on the role of grammatical metalanguage in second language or bilingual learning (Fortune, 2005; Gutierrez, 2008; Ellis, 2009; Hu, 2010). One study which does look at older writers is Robinson's (2005): taking 12 year olds as his focus group, he set out to investigate what metalanguage students use in talking about writing. He argued that 'the role of metalanguage is highly significant in the ongoing development of pupils' language abilities' (2005:39) and concluded that students 'need to learn to use terminology for themselves, rather than listening to the teacher using it' (2005:53).

\section{Grammatical knowledge and metalinguistic understanding}

Further consideration of the relationship between grammatical knowledge and metalinguistic understanding seems pertinent at this point. Explicit grammatical knowledge is often referred to as metalinguistic knowledge which can be brought into conscious awareness and be articulated (Hulstijn, 2005; Roehr, 2006). Such a definition, as noted by Gombert (1992), focuses on students' awareness of their declarative knowledge of language. Other research has paid attention to students' application of their knowledge in metalinguistic activity as a monitoring, regulatory function. The conception of the central role of metalinguistic understanding is underpinned by the social cultural view of grammar represented by Hallidayian Systemic Functional Linguistics and by Vygotsky's (1986) sociocultural theory. As observed earlier, Halliday and Mathiessen (2004:15) define grammar as 'abstract semiosis', a resource to assist students in learning how to mean and the 'driving force' for their language development (ibid 2004:38). Working from the premise that grammar serves as a semiotic mediating tool, to develop knowledge about language means to become metalinguistically aware and to be able to think grammatically about language (Williams, 2004; 2005). Likewise, Vygotsky (1986) argues that what learners will develop as mediational means for future activities is influenced by what they have become aware of in language. Accordingly, the issue of how learners develop metalinguistic understanding as they learn to use grammar as a semiotic tool for writing is an important area for research into the development of knowledge about language.

With this in mind, Bialystok's $(1987 ; 1999)$ work on metalinguistic development in bilingual children is useful: she argues that metalinguistic understanding involves two related components of language processing, analysis and control, which are responsible for language learning and use (e.g. fluent reading, writing coherent texts). She refers to analysis as the ability to represent explicit and conscious knowledge and control as the ability to selectively attend to and apply knowledge (Bialystok, 1987). Bialystok argues that developments in linguistic abilities are a result of developments of analysis and control. This analysis and control framework provides a means with which learners' development of metalinguistic understanding can be described. In the proposed study we will examine learners' reflective capacity in talking about writing 
(analysis) and transferring that metalinguistic understanding into their own writing (control). The concepts of analysis and control have some resonance with Gombert's division of his definition of metalinguistic understanding into, firstly, 'activities of reflection on language and use' (1992:13), similar to Bialystok's analysis; and secondly, individuals' 'ability to monitor and plan their own methods of linguistic processing' (1992:13) which is akin to Bialystok's control. What is common to both is the notion that metalinguistic activity involves both recognising and identifying patterns of language use, and being able to regulate one's own language use and language choices. This seems particularly salient in the context of writing, which is so actively engaged in decision-making.

One key way analysis is represented is in learners' talk about their writing, often referred to as 'metatalk' or metalinguistic discussion (Storch, 2008). This talk can be supported by a specific metalanguage - the language of grammatical, literary, genre or process terminology. Thus, metatalk can provide a valuable window into students' use of metalanguage, particularly their 'regulatory processes' during the talk (e.g. Williams, 2005). The benefit of talk in an instructional context is that can make learning visible and knowledge accessible, and the process of verbalising may support emerging metalinguistic understanding. However, metalinguistic discussions can occur without the use of explicit metalinguistic terminology. Gutierrez (2008), in the context of collaborative writing in a second language, demonstrates how verbalised interactions around a shared writing task can be realised through the use of grammatical metalanguage, where 'attention to language is directly observable in [the student's] words' or without grammatical metalanguage, where there is 'no explicit reference to language' (2008:521). In this way a distinction is made between metalinguistic understanding characterised by use of metalanguage, for example:

I used the passive voice here because it makes it sound more objective.

I don't think the resolution works: it is a bit too dramatic.

And metalinguistic understanding revealed through talk, but without metalanguage, for example:

By putting that information at the start, I have drawn attention to it.

I don't like the way it ends.

Central to this observation are the differing interpretations of the term 'metalanguage' within the disciplinary domains of psychology and linguistics. The psychological view of metalanguage focuses upon language which reveals thinking about language, whereas the linguistic view refers to specialist terminology used to describe language. It is important, then, to investigate the nature of metalanguage used by learners from both disciplinary perspectives to understand the precise role of grammatical knowledge in metalinguistic understanding and writing development.

\section{Implicit and explicit (meta) knowledge}

This discussion of the role of metalanguage and grammatical knowledge in metalinguistic understanding of writing naturally segues into another area where theorisations seem contradictory or conceptually muddled. That is, the distinction between explicit and implicit, or tacit, knowledge. It has long been understood that knowledge can be explicit or implicit, and this distinction is often associated with other binary pairs: procedural-declarative; conscious-unconscious; verbalizable-non verbalizable; direct-indirect tests; automatic-voluntary control and so on. Implicit, or tacit, knowledge is usually deemed to be inaccessible (Kirsh 1991) or non-verbalizable. We have implicit knowledge of how to stand up without falling over but we cannot explain how we do it. Likewise, speakers of their first language know a myriad of grammar rules implicitly such as word order in English but cannot explain them explicitly. In contrast, explicit knowledge is accessible, therefore it is available for reasoning and examination. So, for example, we may have explicit 
knowledge of how to make a cake and can explain it to someone else, or we may have explicit knowledge of what a relative clause is and can explain it to someone else.

In terms of knowledge, the categorizations of implicit and explicit seem reasonably clear. However, it is less clear when metalinguistic knowledge is the theoretical focus. Theoretical studies tend to make binary distinctions between explicit and implicit metalinguistic knowledge and conceive of these as significant in metalinguistic development. For Gombert (1992), epilinguistic or implicit knowledge precedes metalinguistic knowledge. Implicit knowledge includes unconscious knowledge of grammar rules and marks language activities where it is evident that certain linguistic capacities have been mastered but cannot yet be articulated: 'explicit manifestations of a functional awareness of the rules of the organization or use of language' (1992:13). In the context of writing, such implicit knowledge would govern the use of syntactical structures in a sentence which a writer could not explicitly name; and it might include using literary conventions, such as metaphor, or genre conventions such as the formulaic 'Once upon a time...' opening to a fairytale, without being able to consciously note or reflect on these choices. To an extent, the implicitexplicit binary in metalinguistic knowledge is closely aligned to unconscious or conscious control.

However, the 'meta' prefix can be problematic. If you have explicit knowledge of what a verb is, for example, then at the same time, you also have 'meta'-knowledge about language. Despite Gombert's very clear emphasis on unconscious epilinguistic activity and conscious metalinguistic activity, he nonetheless describes epilinguistic as 'unconscious metalinguistic activity' (1992:10). Gombert also argues that all 'awareness', by definition, must be 'meta', and he distinguishes between what he conceives of as spontaneous and automated awareness which is different from conscious awareness and reflectiveness. In similar vein, Masny (1987) considers metalinguistic awareness as implicit knowledge, whereby a learner can produce accurate stretches of language without declarative knowledge of the rules and processes used to produce it. These various conceptualisations do raise significant theoretical questions about whether any 'meta' activity can be unconscious, and if unconscious or automated activities can be deemed 'meta, what the distinction is between linguistic knowledge and metalinguistic knowledge.

Another conceptual issue related to implicit and explicit metaknowledge concerns verbalizability. Several authors, including Roehr (2008), see implicit knowledge as 'knowledge that cannot be brought into awareness or articulated' (2008:179). In contrast, she sees explicit metalinguistic knowledge as 'declarative knowledge that can be brought into awareness and that is potentially available for verbal report'. In other words, the capacity to articulate becomes a key marker of the explicitness of that knowledge. But Camps and Milian (1999) propose a more finely nuanced theorisation of explicit metalinguistic knowledge. They discriminate firstly between verbalizable and non-verbalizable knowledge, defining non-verbalizable knowledge as procedural knowledge which learners can activate in writing without being able to verbally explain it. Of course, this procedural knowledge would be ascribed as implicit by Gombert and Kirsh because it is not conscious. However, there is some support for Camps and Milian's argument: Chen and Jones (2013), working with Australian primary children, found that there are students who know, consciously, what they are doing but struggle to articulate it. Camps and Milian also distinguish between verbalizable knowledge which uses everyday language and that which uses precise metalanguage. This is in harmony with the point made earlier that writers can reveal metalinguistic understanding without use of metalanguage.

Camps and Milian's attribution of procedural knowledge as explicit foregrounds the final conceptual issue we would like to discuss under the umbrella of explicit and implicit boundaries, namely how the concepts of procedural and declarative knowledge relate to metalinguistic understanding in writing. Gombert includes within his conceptualization of explicit metalinguistic knowledge, both declarative knowledge, and 
procedural knowledge: declarative knowledge belong the knowledge of and ability to state rules and principles, whilst procedural knowledge is the ability to put this knowledge into action (1992:191). In the context of writing, the difference between declarative knowledge and procedural knowledge is important and parallels Bialystok's notions of analysis and control: effective metalinguistic knowledge needs to be enacted in the production of a written text. Moreover, Gombert suggests that 'we think that declarative knowledge precedes metalinguistic control and the application of this knowledge' (1992:191) on the basis that we cannot use knowledge we do not have. However, it may be possible to use implicit knowledge procedurally. We know that there is a strong relationship between reading and writing, and that students who are keen readers often draw on their reading experiences in the shaping of written texts (refs) but this may not be available as declarative metaknowledge, or consciously used. Van Lier argues that 'conscious control of language is more truly manifested in linguistic performance than in talking about linguistic performance' (1998:132), signalling the significance of procedural knowledge in writing, but he does not acknowledge that all linguistic performance may not be subject to conscious control. The act of writing is governed by both implicit knowledge and automated processes. Automated processes are those processes which were once foregrounded in consciousness, such as letter shaping, spelling, and punctuation, but also what Hayes and Flower $(1980 ; 1981)$ called 'stored writing plans', where familiarity with a particular form of writing, such as a letter, means the writer no longer needs to think about the form and structure. Automation in writing is an acquired skill which develops with growing competence and experience, but all automated activities can be intentionally monitored if necessary ie brought from unconscious into conscious control. So a writer may at a given point be concerned about the choice of particular word, or the phrasing of a particular sentence, thus drawing an automated process into consciousness. It seems likely that procedural metalinguistic knowledge is crucial to regulating these transitions between conscious and unconscious activity.

Thus, there remains a salient question concerning the directionality of development. Does epilinguistic knowledge necessarily precede metalinguistic knowledge, or can metalinguistic knowledge which through practice and experience become epilinguistic through automation? Explicit teaching of a particular linguistic pattern in writing may represent new metalinguistic knowledge, consciously manipulated at first, but later becomes automated, part of a linguistic repertoire. Does declarative knowledge precede metalinguistic control as Gombert suggests, and what is the relationship between analysis and control? In writing it seems very likely that writers may be able to make metalinguistic choices without the declarative knowledge to name those choices. The binary distinction between implicit and explicit, between analysis and control, and between declarative and procedural, so evident in the literature may be insufficiently nuanced to describe students' metalinguistic development in writing.

This paper has offered an analysis of the conceptual field of metalinguistic development in relation to writing, especially beyond the early years. It has highlighted the paucity of research in this precise area, and has demonstrated how reliance on the evidence from oral or bilingual development does not suffice when writing is being considered. Two points in particular are of note in this respect. Firstly, writing, unlike language acquisition, is by definition always metalinguistic in some way, because every act of writing requires some decision-making about language and the communication of meaning. Secondly, unlike oral development which occurs naturally through social interaction, writing is a learned process, and has to be taught: thus a particular issue is the role of the teacher in supporting the development of metalinguistic understanding. The paper has also drawn attention to the various taxonomies used to describe metalinguistic development and argues that none provide an adequate or appropriately clear description of metalinguistic activity in writing. Thus, in the future, it is important to address these questions through a systematic analysis of what metalinguistic knowledge and understanding students become increasingly 
aware of, able to talk about, and use in their writing across different years of schooling, and the role of teachers in securing this. 


\section{References}

Allan, K.K. (1982). The Development of Young Children's Metalinguistic Understanding of the Word. The Journal of Educational Research, 76 (2,) 89-93.

Barrs, M. (2000). The Reader in the Writer. Reading, 34 (2), 54-60.

Bereiter, C. \& Scardamalia, M. (1987) .The Psychology of Written Composition. Hillsdale, NJ: Lawrence

Bialystok, E. (1999). Cognitive complexity and attentional control in the bilingual mind. Child Development, 70, 636-644.

Bialystok, E \& Barac, R. (2012). Emerging bilingualism: Dissociating advantages for metalinguistic awareness and executive control. Cognition, 122,67-73.

Bialystok, E. (1987). Influences of bilingualism on metalinguistic development. Second Language Research, 3, 154-166.

Bourassa, D., Treiman, R., \& Kessler, B. (2006). Use of morphology in spelling by children with dyslexia and typically developing children. Memory and Cognition, 34 (3), 703-714.

Calkins, L. M. (1983). Lessons from a Child: On the Teaching and Learning of Writing. Portsmouth, New Hampshire: Heinemann.

Camps, A., \& Milian, M. (Eds) (1999). Metalinguistic activity in learning to write. Amsterdam: Amsterdam University Press.

Caravolas, M.,. Kessler,B. Hulme, C. \& Snowling, C. (2005). Effects of orthographic consistency, frequency, and letter knowledge on children's vowel spelling development. Journal of Experimental Child Psychology, 92 (4), 307-321.

Cazden, C. B. (1976). Play with language and meta-linguistic awareness: One dimension of language experience. In. Bruner, J.S., Jolly, A. \& Sylva, K. (Eds.), Play: Its role in development and evolution (pp. 603-608). New York: Basic Books.

Chen, H. \& Jones, P. (2012). Understanding metalinguistic development in beginning writers. Journal of Applied Linguistics and Professional Practice, 9 (1), 81-104

Christie, F., \& Derewianka, B. (2008). School discourse: Learning to write across the years of schooling. London and New York: Continuum.

Cioffi, G. (1984). Observing composing behaviours of primary-age children: The interaction of oral and written language . In Beach, R. \& Bridwell, L.S. (Eds) New Directions in Composition Research. New York: Guildford.

Cisero, C. A., \& Royer, J. M. (1995). The development and cross-language transfer of phonological awareness. Contemporary Educational Psychology, 20, 275-303.

D'warte, J. (2012). Talking about texts: Middle school students' engagement in metalinguistic talk. Linguistics and Education, 23, 123-134.

Dahl, K.L. \& Freppon, P. (1985). Acomparison of inner-city children's interpretations of reading and writing instruction in the early grades in skills-based and whole-language classrooms. Reading Research Quarterly, 31, 50-75.

Downing, J. \& Oliver, P. (1974). The child's concept of a word. Reading Research Quarterly , 9, 568-582.

Ellis, R.. (2004). The definition and measurement of L2 explicit knowledge. Language Learning, 54 (2), 227275.

Ellis, R. (2009). Implicit and explicit learning, knowledge and instruction. In Ellis,R.;, Loewen, S.; Elder, C.; Erlam, R.; Philip, J. \& Reinders, H. )Eds). Implicit and Explicit Knowledge in Second Language Learning, Testing and Teaching Bristol: Multilingual Matters. pp3-30 
Flower, L. \& Hayes, J. R. (1981). A cognitive process theory of writing. College Composition and Communication, 32(4), 365-87.

Fogel, H. \& Ehri. L.C. (2000). Teaching elementary students who speak black English vernacular to write in Standard English: effects of dialect transformation practice. Contemporary Educational Psychology, 25, 212-235

Fontich, X. \& Camps, A. (2014) Towards a rationale for research into grammar teaching in schools. Research Papers in Education, 29(5), 598-625.

Fortune, A. (2005). Learners' use of metalanguage in collaborative form-focused L2 output tasks. Language Awareness, 14, 21-38.

Gombert, E. J. (2003). Implicit and Explicit Learning to Read: Implication as for Subtypes of Dyslexia. Current Psychology Letters: Behaviour, Brain and Cognition, 10 (1), Special Issue on Language Disorders and Reading Acquisition. http://cpl.revues.org/document202.html [accessed Mar 2006]

Gombert, E. J. (1992). Metalinguistic development. Hemel Hempstead: Harvester Wheatsheaf

Graves, D. (1983). Writing: Teachers and Children at Work. Portsmouth, NH: Heinemann.

Gutierrez, X. (2008). What Does Metalinguistic Activity in Learners' Interaction During a Collaborative L2 Writing Task Look Like? The Modern Language Journal, 92 (4), 521-537

Halliday, M.A.K\& Matthiessen, C. (2004). An Introduction to Functional Grammar (3rd Edition). London: Arnold

Hayes, J. \& Flower, L. (1980).. Identifying the organisation of writing process. In Gregg, L. \&. Steinberg, E. (Eds.), Cognitive Processes in Writing, 3-30. Hillsdale, NJ: Lawrence Erlbaum Associates

Heibert, E.; Cioffi , G.; \& Antonak, R. (1984). A developmental sequence in preschool children's acquisition of reading readiness skills and print awareness concepts. Journal of Applied Developmental Psychology, 5, 115-126.

Hu, G. (2010). Metalinguistic knowledge, metalanguage, and their relationship in L2 learners. System,39, 63-77.

Hulstijn, J.H. (2005). Theoretical and empirical issues in the study of implicit and explicit second-language learning. Studies in Second Language Acquisition, 27, 129-140.

Jakobson, R. (1963). Essais de Linguistique Generale. Paris: Editions de Minuit.

Karmiloff-Smith, A.; Grant, J.; Sims, K.; Jones, M-C \& Cuckle, P. (1996). Rethinking metalinguistic awareness: representing and accessing knowledge about what counts as a word. Cognition ,58 (2), 197-219

Kellogg, R. T. (1994). The psychology of writing. Oxford: Oxford University Press.

Kirsh, D. (1991). When is information explicitly represented? In Hanson, PP (Ed) Information, Language and Cognition. New York: Oxford University Press pp340-365

Lin, D. Mcbride-Chang, C. Dorit, A. \& Levin, I. (2011). Mother-child joint writing in Chinese kindergarteners: metalinguistic awareness, maternal mediation and literacy acquisition. Journal of Research in Reading ,34 (4), 426-442.

MacGillivray, L. (1994). Tacit shared understandings of a first-grade writing community. Journal of Reading Behavior, 26 (3), 245-266.

Martello, J. (2001). Talk about writing : metalinguistic awareness in beginning writers. Australian Journal of Language and Literacy, 24 (2), 101-111.

Martin, J. (1985). Factual Writing. Geelong,Victoria: Deakin University Press.

Masny, D. (1987). The role of language and cognition in second language metalinguistic awareness. In Lantolf, J. \&. Labarca, A. (Eds) (1987). Research in Second Language Learning: Focus on the classroom. Norwood, NJ: Ablex pp 59-73 
Murray, D. M. (1982). Learning by Teaching: Selected Articles on Writing and Teaching. Portsmouth, NH: Boynton/Cook.

Myhill, D A (2005). Ways of Knowing: Writing with Grammar in Mind. English Teaching: Practice and Critique, 4 (3), 77-96.

Myhill, D.A. (2011). 'The Ordeal of Deliberate Choice': Metalinguistic Development in Secondary Writers in Berninger, $\mathrm{V}(\mathrm{Ed})$ Past, present, and future contributions of cognitive writing research to cognitive psychology. New York: Psychology Press/Taylor Francis Group. pp247-274

Myhill, D.A. Jones, S.M., Lines, H. \& Watson A. (2012). Re-Thinking Grammar: the Impact of Embedded Grammar Teaching on Students' Writing and Students' Metalinguistic Understanding. Research Papers in Education, 27 (2), 1-28.

Norbert, F. (1999). Bilingualism, writing, and metalinguistic awareness: Oral-literate interactions between first and second languages. Applied Psycholinguistics, 20(4), 533-561.

Nunes, T.,. Bryant, P. \& Bindman, M. (2006). The effects of learning to spell on children's awareness of morphology. Reading and Writing, 19, 767-787.

Painter, C. (1999). Learning Through Language in Early Childhood. London: Cassell

Robinson, M. (2005). Metalanguage in L1 English-Speaking 12-Year-Olds: Which Aspects of Writing Do They Talk About? Language Awareness , 14 (1), 39-55.

Roehr, K. (2008). Metalinguistic Knowledge and Language Ability in University-Level L2 Learners. Applied Linguistics, 29 (2), 173-199.

Rose, D. (2009). Writing as Linguistic Mastery: the development of genre-based literacy pedagogy in Beard, R., Myhill,D., Riley, J. \& Nystrand, M. (Eds) International Handbook of Writing Development, London: SAGE

Simard, D. (2004). Using diaries to promote metalinguistic reflection among elementary school students. Language Awareness, 13 (1), 34-48.

Storch, N. (2008). 'Metatalk in a Pair Work Activity: Level of Engagement and Implications for Language Development'. Language Awareness, 17 (2), 95 - 114.

ter Kuile, H.; Veldhuis, M.; van Veen, S. C.; Wicherts, Jelte M. (2011). Bilingual Education, Metalinguistic Awareness, and the Understanding of an Unknown Language. Bilingualism: Language and Cognition, 14 (2), 233-242.

Thévenin, M.G, Totereau, C.,. Fayol, M. \& Jarousse, J.P. (1999). L'apprentissage/enseignement de la morphologie écrite du nombre en français. Revue Française de Pédagogie, $n^{\circ} 126,39-52$.

Tolchinsky, L. Ed. (2001). Developmental aspects of Learning to Write. Kluwer Academic Publishers

Tunmer, W.E., Bowey, J.A. \& Grieve, R.(1983). The development of young children's awareness of the word as a unit of spoken language. Journal of Psycholinguistic Research, 12, 567-594.

Van Lier, L. (1998). The relationship between consciousness, interaction and language learning. Language Awareness, 7 (2 \&3), 128-145.

Vygotsky, L. S. (1986). Thought and language (Kozulin, A. Ed.). Cambridge, MA: MIT Press

Williams, G. (2004). Ontogenesis and grammatics: Functions of metalanguage in pedagogical discourse. In Williams, G. \& Lukin, A. (Eds.), The development of language:Functional perspectives on species and individuals (pp. 241-267). London: Continuum.

Williams, G. (2005).. Grammatic in schools.In Hasan, R.. Matthiesen, C.M.I.M. \& Webster, J. (Eds.), Continuing discourse on language (pp. 281-310). London: Equinox.

Wilson, A.C. and Myhill, D.A. (2012). Ways with Words: Teachers' Personal Epistemologies of the Role of Metalanguage in the Teaching of Poetry Writing. Language and Education, 26 (6), 553-568. 